DOI

\title{
ПОРІВНЯЛЬНИЙ АНАЛІЗ ЕЛЕМЕНТНОГО СКЛАДУ КОРИ БЕРЕЗИ БОРОДАВЧАСТОї, СУБСТАНЦІї 3 НЕÏ ТА ГРУНТУ
}

๑о. С. Мала

\section{Національний фармацевтичний університет}

РЕЗЮМЕ. За допомогою атомно-емісійної спектрометрії досліджено макро- та мікроелементний склад ґрунту, кори берези бородавчастої та вилученого з неї густого екстракту. Встановлено якісний склад та кількісний вміст 5 макроелементів та 19 мікроелементів.

КЛЮчОВІ СлОВА: елементи, кора, береза бородавчаста, густий екстракт.

Вступ. Біологічна активність макро- та мікроелементів в організмі людини $\epsilon$ високою та різноманітною. Вони беруть участь у формуванні і будові тканин організму, в процесах утворення тканинного білка, у функціях більшості ферментних систем, входять до складу клітин, формують оптимальні сольові склади і кислотно-лужну рівновагу рідини організму, включаючи плазму крові, мають вплив на захисні реакції організму, в значній мірі забезпечують його імунітет. Нормальна функція нервової, серцево-судинної, травної та інших систем неможлива без присутності мінеральних речовин [5]. Дефіцит одного з мінералів може спричинити порушення обміну речовин організму людини. Так, наприклад, кальцій бере участь у формуванні кісткової тканини, входить до складу клітинних структур, він $\epsilon$ обов'язковим компонентом системи підтримання кислотно-лужної рівноваги внутрішнього середовища організму $[10,11]$. Магній потрібний для звільнення енергії вуглеводів при їх окисненні в організмі, бере участь в нормалізації збудливості нервової системи, сприятливо діє на функціональний стан м'язів серця та його кровопостачання, має антиспастичну та судинорозширювальну дію. Мідь бере участь у процесах обміну речовин та тканинного дихання. Цинк має значення для діяльності гіпофіза, статевих, надниркових залоз, бере участь у процесах кровотворення, загоєння ран $[7,8]$.

Одним зджерел мінеральнихсполук $є$ рослини. Тому вивчення макро- та мікроелементного складу рослин $\epsilon$ актуальним та перспективним.

Кора берези бородавчастої (Betula verrucosa Ehrh.) широко використовується в неофіційній медицині як ранозагоювальний, антисептичний, протизапальний засіб, при хронічних гнійних ранах та трофічних виразках, пролежнях, саднах тощо $[4,5]$. Старовинні травники пропонують використовувати кору берези при захворюваннях системи кровообігу, злоякісних новоутвореннях, запаленнях сечостатевої системи та ЛОР-органів [4].
Широкий спектр фармакологічних ефектів кори берези бородавчастої обумовлений наявністю біологічно активних речовин і речовин первинного синтезу - макро- та мікроелементів.

Метою дослідження стало дослідження макро- та мікроелементного складу кори берези бородавчастої, густого екстракту з неї у порівнянні $з$ ґрунтом.

Матеріал і методи дослідження. О6'єктами вивчення були кора берези бородавчастої, грунт, на якому зростали рослини, та густий екстракт кори берези (екстрагент 40 \% спирт етиловий). Кору та грунт збирали на території Харківської області в період сокоруху у березні. Густий екстракт отримували за загальноприйнятими методиками [6].

Дослідження якісного складу та кількісного вмісту макро- та мікроелементів проводили методом атомно-емісійної спектрометрії на базі лабораторії аналітичної хімії функціональних матеріалів та об'єктів оточуючого середовища ДНУ НТК «Інститут монокристалів» НАН України (м. Харків). Калібрувальні графіки в інтервалі вимірюваних концентрацій елементів будували за допомогою стандартних проб розчинів солей металів (ICOPM-23-27). Для розчинення купруму використовували кислоту нітратну кваліфікації ч., а при аналізі інших елементів - реактиви кваліфікації х.ч. та двічі очищену воду. Проби випарювали з кратерів графітових електродів у розряді дуги змінного струму силою 16 А при експозиції 60; як джерело збудження спектрів використовували IBC-28. Реєстрували спектри на фотоплівці за допомогою спектрографа ДФС-8 з трилінзовою системою освітлення щілини та дифракційною решіткою 600 штр. / мм. Фотометрували лінії спектрів при довжині хвилі від 230 до 347 нм. Вимірювання інтенсивності лінії у спектрах досліджуваних проб та градуювальник зразків проводили за допомогою мікрофотометра МФ-1. Відносне стандартне відхилення (для п'яти паралельних вимірів) не перевищувало 30 \% при визначенні числових по- 
Огляди літератури, оригінальні дослідження, погляд на проблему

казників вмісту елементів. Відносне стандартне відхилення для 5 вимірювань не перевищувало 30 \% при визначені числових значень концентрацій елементів [1-3].

Результати й обговорення. У результаті дослідження визначено 24 мінеральних елементи. Результати наведено у таблиці 1. Встановлено, що для усіх об'єктів дослідження можна встано- вити наступний ряд накопичення елементів за зменшенням їх вмісту. Для кори - макроелементи накопичувалися: $\mathrm{Na}>\mathrm{K}>\mathrm{Si}>\mathrm{Ca}>\mathrm{Mg}>\mathrm{P}$; мікроелементи - Al>Fe>Mn>Cu>Zn>Ni>Mo, для густого екстракту макроелементи: $\mathrm{Na}>\mathrm{Si}>\mathrm{K}>\mathrm{Ca}>\mathrm{Mg}>\mathrm{P}$; мікроелементи - $\mathrm{Fe}>\mathrm{Al}>\mathrm{Mn}>\mathrm{Cu}>\mathrm{Zn}>\mathrm{Ni}>\mathrm{Mo}$ і для грунту - макроелементи: $\mathrm{K}>\mathrm{Na}>\mathrm{Ca}>\mathrm{Si}>\mathrm{P}>\mathrm{Mg}$; мікроелементи - $\mathrm{Fe}>\mathrm{Al}>\mathrm{Mn}>\mathrm{Ni}>\mathrm{Cu}>\mathrm{Zn}>\mathrm{Mo}$.

Таблиця 1. Макро- та мікроелементний склад кори берези бородавчастої в порівнянні з густим екстрактом кори та ґрунтом

\begin{tabular}{|c|c|c|c|}
\hline \multirow{2}{*}{$\begin{array}{c}\text { Символ } \\
\text { елемента }\end{array}$} & \multicolumn{3}{|c|}{ Вміст елемента, (у мг / 100 г) } \\
\cline { 2 - 4 } & кора* $^{*}$ & густий екстракт кори** & \multicolumn{1}{|c|}{ грунт $^{* *}$} \\
\hline $\mathrm{Na}$ & 3200,00 & 2100,00 & 1100,00 \\
\hline $\mathrm{K}$ & 1360,00 & 540,00 & 570,00 \\
\hline $\mathrm{Ca}$ & 260,00 & 110,00 & 91,00 \\
\hline $\mathrm{Mg}$ & 175,00 & 39,00 & 100,00 \\
\hline $\mathrm{P}$ & 20,00 & 8,00 & 680,00 \\
\hline $\mathrm{Al}$ & 26,00 & 4,70 & 130,00 \\
\hline $\mathrm{Mn}$ & 7,00 & 0,90 & 3400,00 \\
\hline $\mathrm{Fe}$ & 15,00 & 7,00 & 6,00 \\
\hline $\mathrm{Ni}$ & 0,04 & 0,02 & 3,00 \\
\hline $\mathrm{Zn}$ & 0,70 & 0,28 & 1,00 \\
\hline $\mathrm{Mo}$ & 0,15 & 0,03 & 0,05 \\
\hline $\mathrm{Si}$ & 0,03 & 0,01 & 410,00 \\
\hline
\end{tabular}

Примітки: «*» - в розрахунку на абсолютно суху сировину, «**» - в розрахунку на абсолютно сухий залишок, вміст Со<0,03, $\mathrm{Cd}<0,01, \mathrm{As}<0,01, \mathrm{Hg}<0,01, \mathrm{Bi}<0,03, \mathrm{~S} n<0,2, \mathrm{Ag}<0,03, \mathrm{Ga}<0,01, \mathrm{~S} r<0,01, \mathrm{~V}<0,01, \mathrm{Ti}<0,01$.

Вміст важких металів знаходився в межах вимог гранично допустимих концентрацій для сировини та харчових продуктів, що відповідає вимогам ДФУ [1].

У корі вміст натрію був майже втричі вищий, ніж у грунті та в 1,5 раза вищий, ніж у густому екстракті (відповідно 3200,00 мг / 100 г, 1100,00 мг / 100 г та 2100,00 мг / 100 г). Калій в 1,3 раза більше містився у грунті, ніж у корі, та в 3,6 раза більше, ніж у густому екстракті (1760,00 мг / 100 г, 1360,00 мг / 100 г та 540,00 мг / 100 г). Вміст кальцію у грунті (570,00 мг / 100 г) був більший ніж у корі в два рази (260,00 мг / 100 г) та більш ніж у п'ять разів вищий за вміст у густому екстракті (110,00 мг / 100 г). Сіліціум вилучався у густий екстракт в кількості 550,00 мг / 100 г, що у 1,3 раза більше, ніж у грунті (410,00 мг / 100 г) та у 1,7 раза вище, ніж у корі (320,00 мг / 100 г). В значних кількостях магній накопичувався у корі (175,00 мг / 100 г), а у екстракт вилучалося у 4,5 раза менше (39,00 мг / 100 г). У грунті вміст цього елемента склав 91,00 мг / 100 г, що у 2 рази менше, ніж у сировині і у 2,3 раза менше, ніж у субстанції. Вміст фосфору у грунті, порівняно з корою, в 5 разів вищий $(100,00$ мг / 100 г та 20,00 мг / 100 г відповідно) та більш ніж у 10 разів вищий за вміст у субстанції (8,00 мг / 100 г). Максимальний вміст заліза визначено у грунті (3400,00 мг / 100 г), проте у корі та густому екстракті цей елемент накопичувався у незначних кількостях (15,00 мг / 100 г та 7,00 мг / 100 г відповідно). Така закономірність спостерігалась для алюмінію та мангану. Так, максимальна кількість алюмінію спостерігалась у грунті (680,00 мг / 100 г), значно нижчий вміст у корі та густому екстракті (26,00 мг / 100 г та 4,70 мг / 100 г відповідно). Манган максимально накопичувався у грунті (130,00 мг / 100 г), а у корі та субстанції вміст елементу становив 7,00 мг / 100 г та 0,90 мг / 100 г відповідно.

Висновки. Методом атомно-емісійної спектрометрії визначено якісний склад і кількісний вміст макро- та мікроелементів у корі берези бородавчастої та густому екстракті, порівняно 3 грунтом. Встановлено 24 мінеральних сполуки. У досліджуваних об'єктах було визначено високий вміст життєво важливих елементів - натрію, калію, кальцію, марганцю та сіліціуму. Отримані дані будуть використані при стандартизації сировини та субстанцій з неї. 
Огляди літератури, оригінальні дослідження, погляд на проблему

\section{ЛІТЕРАТУРА}

1. Державна Фармакопея України / Держ. П-во «Науково-експертний фармакопейний центр». - 1-е вид., допов. 2. - Х. : РІРЕГ, 2008. - 620 с.

2. Зырин Н. Г. Методические указания по спектрографическому определению микроелементов в почвах и золе растений / Н. Г. Зырин, А. И. Обухов, Г. Д. Белицина. - М., 1971. -105 c.

3. Зырин Н. Г. Спектральный анализ почв, растений и других биологических объектов / Н. Г. Зырин, А. И. Обухов. - М., 1977. -333 с.

4. Корсун В. Ф. Фитотерапия кожных болезней: справ. / В. Ф. Корсун, А. Е. Ситкевич, Ю. А. Захаров. Мн. : Беларусь, 2001. -446 с.

5. Нагорная Н. В. Роль минеральных веществ в физиологии и патологии ребенка // Здоровье ребенка. -2008 . №. 6. - С. 15.

6. Промислова технологія ліків: у II томах / В. І. Чує- шов, М. Ю. Чернов, Л. М. Хохлова [та ін.] -Х. : Основа; Видва УкрФа, 1999. - Т. II. - 704 с.

7. Baydil B. Serum macro-micro element responses to acute maximal physical exercise / B. Baydil // World Appl. Sci. J. - 2013. - Vol. 23 (7). - P. 945-949.

8. The potential impact of soil ingestion on human mineral nutrition / Hooda P. S. [et al.] // Science of the Total Environment. - 2004. - T. 333, № 1. - C. 75-87.

9. Kara $\mathrm{E}$. The effects of acute submaximal exercise on trace ekement metabolism / E. Kara // HelthMED. 2011. - Vol. 5 (6). - P. 1580-1585.

10. Picard H. Utilisation therapeutique des oligoelements / H. Picard - P. : Libr. Malaine, 1965. -176 p.

11. Human-centered interactivity of visualization tools: Micro-and macro-level considerations / Sedig K. [et al.] // Handbook of Human Centric Visualization. - Springer New York, 2014. - C. 717-743.

\section{THE COMPARATIVE ANALYSIS OF ELEMENTS OF CORTEX BETULA BIRCH, SUBSTANCE OF IT AND SOIL}

๑O. S. Mala

\section{Національний фармачевтичний університет}

SUMMARY: using atomno-emission spectrometry method the study of element composition of cortex betula birch, substance of it and soil was conducted. There are 5 macro-elements and 19 micro-elements were determined in the investigated objects.

KEY WORDS: elements, bark, betula verrucosa, thick extract. 